\title{
An Islamic Approach to Inequality and Poverty
}

\author{
Asad Zaman \\ Vice Chancellor \\ Pakistan Institute of Development Economics (PIDE), Islamabad
}

\begin{abstract}
We argue that ways of thinking about poverty changed dramatically due to the Great Transformation in Europe which created a market society. These ways spread to the rest of world due to the colonization and global conquest of Europe. The market society requires a labor market which de-humanizes people turning them into commodities. This and other related changes in attitudes toward wealth and poverty are the sources of the difficulties created by poverty and inequality. An Islamic approach requires re-creation of society on the basis of generosity and cooperation, values which are antithetical to greed and competition, the basis of market societies. We sketch a three-dimensional approach to resolving problems created by inequalities and poverty, based on spiritual, social, and institutional components. In each area, the source materials of Islam and Islamic history provide ample guidance and precedent for a radically different approach to these problems.
\end{abstract}

Keywords: Poverty, Inequality, Poverty alleviation, The Great Transformation, Multi-dimensional poverty, Zakāh, Șadaqāt, Awqāf.

JEL Classification: P4, I3.

KAUJIE Classification: N2, N3, N4, N7.

\section{Introduction}

Allah Almighty says:

But is it they who distribute thy Sustainer's grace? [Nay, as] it is We who distribute their means of livelihood among them in the life of this world, and raise some of them by degrees above others, to the end that they might avail themselves of one another's help - [so, too, it is We who bestow gifts of the spirit upon whomever We will]: and this thy Sustainer's grace is better than all [the worldly wealth] that they may amass. (Qur'ān, 43:32)
This verse makes it very clear that Allah Almighty has created inequality purposefully, and one of the important purposes is that it makes us need one another so that we can help one another. This puzzles modern minds who are used to thinking of poverty as an evil which must be combatted and destroyed. This modern line of thinking (that poverty is a social evil) also appears to be supported by many verses of the Qur'ān and other Islamic source materials which strongly urge the feeding of the poor and describe our 
collective social responsibilities in providing for the basic needs of all members of the society. On the one hand, Allah has created poverty and inequality for a purpose, and on the other hand, it appears that $\mathrm{He}$ is urging us to remove these characteristics from society.

Our goal in this article is to explain the Islamic viewpoint regarding the understanding of inequality and poverty. However, achieving this goal requires a detour through the history of Western intellectual developments which led to modern ways of thinking about poverty now dominant throughout the world. In The Idea of Poverty, Gertrude Himmelfarb (1984) has documented how poverty ceased to be the natural condition and became a social problem in the early stages of the industrial revolution. While it is true that poverty has been nearly universally present, ideas about poverty have undergone a radical transformation. While modern minds, shaped by market societies, see poverty as an obvious evil which must be eliminated to improve social welfare, pre-modern thought accepted poverty as a natural phenomenon and did not attach any stigma to it. Indeed, in medieval Europe, poverty was honored and idealized and stigma was attached to wealth and the wealthy. The Bible states that "Blessed are the poor" (Matthew 5:3, New International Version) and Christian monks who took vows of poverty were honored for living this ideal. Similarly, the Bible states that the love of wealth is the source of all evil, "For the love of money is a root of all kinds of evil" (Timothy 6:10).

Paradoxically, we can find Islamic source materials to support both viewpoints: the pre-modern view of poverty as honorable and wealth as evil, as well as the opposite view of poverty as evil and wealth as a blessing. Modern Islamic thought has been shaped by the experience of living in market societies which spread throughout the world as a result of the European conquest and colonization of the globe. One way to remove the blinders created by this experience is to study the historical process of transition from traditional to market societies. It is only after going back to the pre-modern conceptions of society as an organic whole that we can resolve these paradoxes, and realize that there is perfect harmony between the social imperative of struggling to remove poverty and the fact that poverty and inequality serve many useful social purposes.

\section{The Great Transformation}

Karl Polanyi (1944) has described how possibilities of surplus production, created by the industrial revolution, led to the emergence of a market society overturning traditional ways of organizing production processes. The resulting 'great transformation' changed the political, social, and economic structures of European societies. These external institutional transformations were accompanied by equally radical transformations in the philosophical frameworks for thinking about the world ${ }^{(1)}$. Large libraries can be filled describing the multi-dimensional processes of change which affected all lives on the planet. In this article, we focus on only one element most relevant to our topic: the legitimization of the pursuit of wealth.

After the completion of the Spanish reconquest of al-Andalus in 1492, a flood of knowledge from the vast libraries of Islamic Spain ended the dark ages of Europe. European animosity to Islam has led to the suppression and concealment of these facts in Eurocentric histories which present the 'enlightenment' as a spontaneous and uncaused event ${ }^{(2)}$. From the sixteenth to the eighteenth century, the Catholic Church struggled to suppress heretical ideas from Islamic Spain but failed. In the process of this struggle between "science" and religion, spanning centuries, the unity of the Church was shattered and violent battles between opposing religious factions led to general disenchantment with religion in Europe ${ }^{(3)}$. Prior to this experience, society had been conceived of as an organic whole consisting of different parts which work together for a common purpose. With respect to this metaphor, acceptance of inequality was natural ${ }^{(4)}$. However, bitter experience with

(1) Key references are Polanyi (1944) on political and economic transitions, Tawney (1937) on changes in moral thought, and Manicas (1987) on changes in theoretical frameworks for social science.

(2) See C. K. Raju: Is Science Western in Origin, or Jack Goody: The Theft of History.

(3) See Zaman (2011) "European Transition to Secular Thought: Lessons for Muslims" for details.

(4) As Tawney (1937) discusses at length, the metaphor of "the body" is used for society in the pre-modern European writings. This implies the acceptance of inequality as natural, and indeed necessary; this is exactly in accordance with verse (43:32) of the Qur'ān cited above. Different parts of the body, the foot, head, arms, heart, etc. all perform extremely different functions and there is no question of equality. Nonetheless, all parts act in harmony and are united in an organic whole. Exactly this same metaphor is used in Islamic teachings which refer to the ummah as one body, where if one part is wounded, the entire body feels the pain. 
bloody battles between Catholics and Protestants led to the emergence of secular thought which created a different way of looking at society.

\subsection{The Transition to Secular Thought}

Secularism sought to mediate violently conflicting religious views by putting religion aside in working out arrangements to live together in peace. Oakeshott (1975) writes that this new concept "societas" stood in dramatic contrast with traditional conceptions: "Juristically, societas was understood to be the product of a pact or an agreement, not to act in concert but to acknowledge the authority of certain conditions in acting" (p. 201). A modern society comes into being as an agreement to live together and abide by common rules necessary to ensure peace and to resolve conflicts between subgroups with different purposes. This transition from a traditional society as an organic whole, to a modern society as a collection of competing communities without com-mon values or objectives, led to new ways of conceptualizing relations between the individual and the state.

Hobbes was the first political philosopher to articulate the new paradigm for politics. He saw the collectivity as a "war of all against all" (Hobbes, 1949, p. 13) which required a government to regulate, mediate and resolve conflicts, to prevent lives from being "nasty, brutish and short" (Hobbes, 1909, p. 99). The emergence of the rule of (arbitrary) laws became necessary to govern such a society since there was no agreement on common traditions or religious authority. One important and surprising consequence of the loss of common purpose for society was the elevation of certain intermediate goals (freedom and wealth) to the status of final purposes.

\subsection{The Rise of Wealth and Freedom}

In a traditional society, people are tied to each other by a collection of responsibilities and social commitments that none can over-ride on the basis of personal preference. Duty and responsibility take precedence over freedom. Similarly, the pursuit of wealth and luxury is harmful to spiritual development and is universally discouraged in all traditions. For example, the Qur'ān (42:27) states that excess wealth can lead people to become rebellious. Similarly, appetitus divitiarum infinitus, the unbridled indulgence of the acquisitive appetite, is considered to be a deadly foe of Christianity.
It should be clear that both freedom and wealth are intermediaries - they are not valuable for themselves but as a means to achieving other goals. However, final goals are disputed by communities in a secular society. As a result, a secular society can only agree on the intermediate goal of allowing all people freedom and wealth so that each can pursue their own separate concepts of the good life. The process of transition, in which characteristics and qualities known to be harmful to society came to be tolerated and even preferred, took centuries to accomplish. There were many stages in this transition. Initially, equality and freedom were not granted to individuals, but to communities living within common national boundaries under common rules. Later, as communities dissolved gradually under the influence of increasing individualism, these rights were extended to individuals. Eventually, society as a whole lost sight of the fact that these goals, freedom and wealth, were only sought as intermediaries to some higher purpose and converted them to final goals. For example, Max Weber (1930, Chapter 2) writes that the "spirit of capitalism" is the pursuit of wealth as an end in itself to the point of being "absolutely irrational" (p. 53). Similarly, Mankiw and Taylor $(2007$, p. 9) state in their best-selling textbook on economics that the reason for the excellent functioning of decentralized market economies is that all participants are motivated by self-interest. This self-interest works better than love and kindness in terms of promoting social welfare. This idea that selfishness and greed are legitimate, and take precedence over social welfare, is unique to modern societies and not compatible with fundamental Islamic values.

Massive production of surplus, far above and beyond basic needs, is one of the defining characteristics of capitalism. Traditional societies value self-sufficiency and dislike excessive consumption. Surplus production was one of the driving forces behind the global conquest and colonization by Europe. In order to find markets for their surplus production, Europeans, driven by greed and the desire for excessive wealth, destroyed well-functioning institutions and self-sufficient economies converting them into colonies for provision of raw materials to European factories. In the process, wealth was siphoned from all over the globe to be concentrated in Europe resulting in massive wealth in Europe 
combined with massive poverty elsewhere. This historical process lies at the root of the extreme disparities in wealth we see across the globe where the GNP per capita of Luxembourg is 100 times that of the poorest countries ${ }^{(5)}$. Stavrianos (1981), who has described this history, remarks that the wealth of the colonizers and the poverty of the colonies are opposite sides of the same $\operatorname{coin}^{(6)}$.

\subsection{The Fall of the Poor}

As already discussed, poverty is not regarded as a social problem or an evil in traditional societies. Inequality is accepted as a natural part of social organization, which requires different people to do different types of work and occupy different status while working together in harmony for common goals. A traditional society has many mechanisms which work to alleviate the suffering that can be caused by poverty:

1. Religion teaches men to be content with their lot in this world and strive to achieve the felicity of the hereafter. In particular, Islamic teachings ask the poor not to envy the rich and the rich not to flaunt their wealth. Also, conspicuous consumption is prohibited by Islam. Instead, the rich are strongly encouraged to give from their excess wealth to the poor.

2. Natural human tendencies for compassion and generosity lead those with excess to support those in need.

(5) Data from Wikipedia shows Luxembourg at USD 103,199, while the poorest 25 countries have GNP below USD 1000 per capita. ( https://en.wikipedia.org/wiki/List of countries by_GDP_(nominal)_per_capita).

(6) Quote from Stavrianos (1981, pp. 34-35): "The "backwardness" of colonial peoples was taken for granted. The "natives" were viewed as inherently different from and inferior to, their European rulers... Colonial rule generally was considered to be not the cause, but the only feasible solution for the prevailing backwardness... it is beginning to be realized that the underdevelopment of the Third World and the development of the First World are not isolated and discrete phenomena. Rather they are organically and functionally interrelated. Under-development is not a primal or original condition, to be out-grown by following the industrialization course pioneered by Western nations. The latter are overdeveloped today to the same degree that the peripheral lands are underdeveloped. The states of developedness and under-developedness are but two sides of the same coin".
3. Social institutions are created to provide systematically for the poor. In Europe, there were many such church-based organizations. In Islamic countries, the waqf provided systematic support and shaped the fabric of Islamic societies.

4. The poor have access to natural resources, which the land provides generously, allowing them to eke out a living; for example, fishing, hunting, agriculture, or cutting wood and selling it.

All of these traditional pillars of support for the poor were swept away in the process of the transformation of traditional society into a market economy in England, the heartland and birthplace of capitalism. Complex political circumstances in England led to a massive landgrab by the aristocracy, "a revolution of the rich against the poor" (Polanyi, 1944, p. 35), in the form of enclosures which turned vast areas of land into the private property of the rich. Church properties were also seized so that religious institutions which supported the poor ceased to function. Enclosures also deprived the poor of access to the land and left them with the alternative of starving or laboring in the newly emerging factories under miserable working conditions for low wages. As a final stroke, Malthusian philosophy created the idea that the poor were to blame for their own conditions (due to excessive procreation) and did not deserve the sympathy of the rich. The insightful analysis of Polanyi suggests that all of this was necessary to create the labor market which was required for largescale production in capitalist society.

\subsection{Creation of Labor Market}

Central to the changes labeled the Great Transformation by Polanyi was the need of large-scale production for a labor market - a place where significant fractions of human lives can be purchased on the open market. One of the central arguments of Polanyi is that traditional support and sympathy for the poor interfered with the creation of the labor market required for operations of large-scale industries in early capitalism $^{(7)}$. The labor market creates an artificial commodity - human lives - for sale in the market.

(7) Zaman (2010b) provides a review and summary of Polanyi (1944) in the context of Islamic economics. 
The creation of the labor market required for the functioning of modern capitalism necessitates several changes in attitudes towards poverty. First, capitalists employ labor which creates class differences giving the bosses superiority and making laborers inferior. Second, the production process is not considered as a joint enterprise for the provision of services to society (as in the Islamic view to be described later). Instead, it is an enterprise to make profits for the capitalist often at the expense of society. Exploitation of laborers increases profits and hence is one of the key components of capitalism. This creates alienation and anomie since labor is no longer engaged in socially meaningful work. Instead, he sells his services out of the necessity of earning a living. Finally, in order to prevent revolutions, capitalism also requires the laborers to believe in the necessity of their enslavement and exploitation. This is accomplished by the educational processes which create numerous mythical justifications. One of these is the famous production function, according to which laborers receive their marginal product while capitalists receive their marginal product so that each receives a just payment for their share of the product ${ }^{(8)}$. In addition, economic theory shows that firms earn no excess profits so that no demands can be made by laborers for a just and equitable share in the profits of the firm. In a reality ignored by textbooks, big corporations make trillions of dollars of profits. If these were distributed justly, the major deprivations of poverty could easily be eliminated, but at the cost of lowering corporate profits.

Whereas poverty is a natural phenomenon in traditional society, it is a serious social problem in market economies that emerged after the industrial revolution created the possibility of large-scale production. Once the poor are deprived of all the pillars of support available to them in a traditional society, informed that they are responsible for their own condition, and offered no hope of a better life in the hereafter, they will naturally create social unrest. Polanyi (1944, Ch. 3) describes how enclosures of land caused a large-scale uprooting of small peasants

(8) Cohen \& Harcourt (2003) show that the Cambridge Capital Controversy, initiated by Joan Robinson, was never resolved. Thus, the construct of "capital" used to create this appearance of symmetry between capital and labor cannot be justified. Nonetheless, the controversy was buried and is rarely mentioned in textbooks which continue to use this same theory. eking a living off the land and created a labor force which could be used as fodder for the 'satanic mills' at the heart of the industrial revolution. Poverty as a social problem came into being for the first time during this period, and as capitalism has spread across the planet, it has carried the labor market and poverty along with itself. The cures for the problem lie in dimensions radically different from those which can be conceived in capitalist societies.

\section{The Spiritual Dimension}

The Islamic worldview is radically different from that created and fostered by market societies in which we currently live. This worldview came as a stranger and created a revolution. Ignorant Arabs, living in a primitive society, absorbed this message and became leaders of the world. They created a vibrant civilization which lasted for more than a thousand years enriching the lives of all on the planet ${ }^{(9)}$. Over the past few centuries, decay and degeneration has set in within the Islamic civilization while primitive European tribes acquired civilization and weapons, and came to dominate the globe. As a result of the great transformation which took place in Europe, modern society is based on radically different principles from those of traditional societies and especially of Islamic societies. An Islamic approach to poverty and inequality cannot be applied as band-aids to a radically different social, political, and economic system. The revolutionary approach of Islam requires a revolutionary framework to implement.

The Islamic response to problems created by inequality and poverty is crafted along three dimensions - spiritual, social, and institutional. We will discuss each of the three in separate sections. The present section deals with the spiritual component.

A central and core element of the Islamic approach is that this world is a trial and that the results of this trial will be seen in the afterlife. All our struggles on this Earth are purely for the sake of Allah:

Say: Lo! my worship and, my sacrifice and my living and my dying are for Allah, Lord of the Worlds. (Qur'ān, 6:162)

(9) Marshall Hodgson (2009) provides a good overview. 
The Qur'ān provides us with guidance on how to carry out this struggle so that we can achieve the success in the hereafter. The Prophet Muhammad (may the peace and blessings of Allah be upon him) was sent as a Messenger and as a model of excellence in behavior so that we would have a practical demonstration of the ways of living required and preferred by Allah. For convenience, we mention four principles related to wealth which we need to learn to achieve spiritual progress:

1. Learning indifference to wealth.

2. Learning generosity and compassion.

3. According dignity and equality to the poor.

4. Learning moderation in living and giving.

\subsection{Learning Indifference to Wealth and Luxury}

One of the central Islamic teachings with respect to wealth, in common with all other religious traditions, is the cultivation of indifference to wealth. It is not wealth itself which is undesirable; rather, it is attachment to, or love of, wealth which is deadly. Spiritual progress occurs when we cleanse the heart of the love of material possessions and replace this by the love of God. This point is clarified in several source materials in the Qur'ān and the ahāalìth. The Qur'ān states that success in the hereafter depends on our loving Allah Almighty, his Prophet (may the peace and blessings of Allah be upon him), and His dinn (religion) more than all our material possessions:

Say: If your fathers, and your sons, and your brethren, and your wives, and your tribe, and the wealth ye have acquired, and merchandise for which ye fear that there will be no sale, and dwellings ye desire are dearer to you than Allah and His messenger and striving in His way: then wait till Allah bringeth His command to pass. Allah guideth not wrongdoing folk. (Qur'ān, 9:24)

Similarly, al-Bukhari reports that the Prophet Muhammad (may the peace and blessings of Allah be upon him) said:

Hakim! Wealth has a deceptive appearance. It appears to be very sweet (but it is really not so). It is a blessing when earned with contentment of heart, but there is no satisfaction in it when it is got with greed. (al-Bukhari, 1422H, 2:123, hadìth no. 1472)

This clarifies some apparent conflicts in Islamic source materials, some of which treat wealth as a blessing while others teach the opposite lesson.
Depending on the state of spiritual progress, wealth can be a blessing or a curse. As the Qur'ān states, both wealth and poverty are trials and not markers of the pleasure or displeasure of God:

Now, as for man, when his Lord trieth him, giving him honour and gifts, then saith he, (puffed up), "My Lord hath honoured me." But when He trieth him, restricting his subsistence for him, then saith he (in despair), "My Lord hath humiliated me!" (Qur'ān, 89:15-16)

Failure in the trial by wealth occurs if we become arrogant or proud or feel that we deserve the wealth due to our merits or skills. This feeling of entitlement was expressed by Qaroon:

This [wealth] has been given to me only by virtue of the knowledge that is in me! (Qur'ān, 28:78).

Instead, the Qur'ān teaches us that all dominion belongs to Allah alone and $\mathrm{He}$ gives from this to whomsoever He wishes. Any wealth that we have is a gift of Allah and we should give to others out of the bounties that Allah Almighty has given to us. Qaroon is reminded to:

do good [unto others] as God has done good unto thee. (Qur'ān, 28:77)

If possession of wealth makes us feel gratitude to Allah, and we follow the rules of the Shari' ah in acquiring and spending wealth in the path of Allah, then wealth is a great blessing. If instead, we become proud and arrogant due to this wealth, then wealth can cause great harm to our spiritual development and to others. The Qur'ān states that wealth can cause some to become rebellious:

And if Allah were to enlarge the provision for His slaves they would surely rebel in the earth, but $\mathrm{He}$ sendeth down by measure as He willeth. Lo! He is Informed, a Seer of His bondmen. (Qur'ān, 42:27)

The love of wealth and luxury has been built into the hearts of men. Spiritual progress occurs when we learn to reduce or eliminate this love, which corrupts our hearts, and replace it with the love of Allah, His Prophet (may the peace and blessings of Allah be upon him), and His dīn. This is known as "tazkiyah"; cleansing or purification of the heart. Struggling against problems created by inequality and poverty leads to this kind of spiritual progress. If we give away the things we love most to the poor, this will 
reduce our love of material possessions and will also create sympathy and consideration for the poor. Both of these are characteristics of soft hearts which are required of believers.

\subsection{Learning Moderation in Lifestyles}

Islamic teachings place stress on living a simple lifestyle. For example,

O Children of Adam! wear your beautiful apparel at every time and place of prayer: eat and drink (freely): But waste not by excess, for Allah loveth not the wasters. (Qur'ān, 7:31)

The verse clarifies that Islam does not require us to be ascetics; we can eat and drink and wear beautiful clothes. Similarly, Allah states that:

Say: Who has forbidden the beautiful (gifts) of God which $\mathrm{He}$ has produced for His servant and $[$ tayyibāt $]$ things clean and pure (which $\mathrm{He}$ has provided) for sustenance?"' (Qur'ān, 7:32)

At the same time, we must display moderation in consumption and not indulge in excess or wasteful spending (isräf and tabdhìr).

Verily spendthrifts are brothers of the shayattinn [Satans]; and the shaytān [Satan] is to his Lord, ungrateful. (Qur'ān, 17:27)

In particular, we should not lead luxurious lifestyles or seek to emulate them. Verse $(3: 196)$ of the Qur'ān asks us not to be deceived by the apparent pomp or luxury of the lifestyles of wealthy non-Muslims. Similarly, verse (Qur'ān, 43:33) states that Allah would have provided non-Muslims with houses of gold and silver, but that this trial would have proven too difficult for most Muslims.

Modern conventional approaches based on contemporary theories do not take into account these spiritual dimensions. As a result, these approaches are seriously deficient on many fronts. There are two important sources of poverty. One is the creation of extremely wasteful lifestyles and the creation of luxuries. This is a property of the market economy where supply is created to match demand. In The Affluent Society, Galbraith (1998) noted that corporations advertise to create the demand required to match their excessive production of unnecessary goods. Thorstein Veblen (1899) noted the importance of conspicuous consumption where the wealthy buy goods in order to flaunt their wealth (like Qaroon) instead of being driven by needs. These problems of excessive consumption are central to solving the problem of poverty, but are not mentioned in conventional approaches which shy away from discussing the roots of the problem. For example, Goodwin, Ackerman, and Kiron (1997) write that:

The crucial period for the formation of modern American consumerism was in the 1920s, when manufacturers confronted the possibility that once basic needs were met mass consumption might not follow mass production and rising productivity levels. In response, business helped create the "American Dream," a materialistic image of success to which everyone might aspire. But for many families, this dream was a moving target, always out of reach. Households would aspire to one level of material affluence, attain it and become habituated to it, and then aspire to the next level. The role of business in promoting this cycle of aspiration and habituation is essential to understanding the cycle of work-and-spend. (p. 47)

This encouragement of wasteful spending (isrä $f$ and tabdhìr), forbidden in Islam (Qur'ān, 17:26-27), is leading to the destruction of planetary resources at a catastrophic rate. Furthermore, the lifestyles being promoted are not sustainable and are being purchased by short-changing future generations. Richard Robbins (1999, p. 209) writes that about 5 hectares of productive land are required to maintain the lifestyle of an average person in a rich country, while only 1.7 hectares per person are available worldwide. The process of fulfilling demand for luxurious lifestyles leads to large-scale destruction of planetary resources in a way that is clearly unjust for both the deprived among our contemporaries and future generations.

Several verses of the Qur'ān forbid conspicuous consumption. For example, in verses (Qur'ān, 28:7884) Qaroon is commanded not to flaunt his wealth. The Qur'ān (45:23) condemns those who have taken their desires as their God and states that paradise is for those who fear God and restrict their desires (Qur'ān, 79:40-41). In a hadìth, the Prophet Muhammad (may the peace and blessings of Allah be upon him) recommended sharing fruits with neighbors or else, to use it secretly so that the neighbors' children would not see them and feel envious (al-Bayhaqi, 2003, 12:104, hadìth no. 9113). Similarly, he rebuked a companion for the extravagant construction of a dome above the door of his house 
(Abu Dawood, 2009, 7:522, hadìth no. 5237). Nonetheless, growth required for capitalism encourages luxurious and conspicuous consumption to generate demand for equally wasteful and excessive production. This creates a rat-race where artificial demand is generated and met by unnecessary production leading to increasing consumption and production. As the famous Easterlin Paradox (2010) demonstrates, this process of additional consumption due to increasingly higher standards of living does not add to welfare and happiness.

Welfare and happiness do not come from external circumstances, but from cultivating good characteristics. For instance, the poor are commanded not to envy the rich (Qur'ān, 4:32), and not to seek to emulate their lifestyles (Qur'ān, 9:55). There is a hadìth to the effect that "True richness is contentment of the heart" (al-Bukhari, 1422H, 8:95, hadith no. 6446). This is borne out by recent research on happiness (see, for example, Sonja Lyubomirsky, 2008) which shows that wealth creates short-run and temporary gains in happiness, but long-run gains require the cultivation of character traits like gratitude for what one has and visualization and pursuit of ideals. As a means to happiness, the pursuit of wealth turns out to be an illusion as the Qur'ān (3:185) states.

\subsection{Learning Generosity and Compassion}

A central element in the Islamic approach to poverty and inequality is the cultivation of the character trait of generosity. For instance,

Allah commands justice, the doing of good, and generosity to fellow men. (Qur'ān, 16:90)

There are more than 100 verses of the Holy Qur'ān which encourage generosity, giving to others for the sake of the love of Allah, and discourage and condemn miserliness and stinginess. In addition to encouragement, promises of multiplied rewards, exhortations, and recommendations, the Qur'ān provides us with the tools to cleanse our hearts of the love of wealth:

[But as for you, O believers,] never shall you attain to true piety unless you spend on others out of what you cherish yourselves; and whatever you spend verily, God has full knowledge thereof. (Qur'ān, 3:92)
By spending, or giving away, our prized possessions, we will reduce the love of material goods in our hearts, and we will increase our sympathy and compassion for others. The Qur'ān states that people of piety spend on others to purify their own hearts:

[He] who gives [from] his wealth to purify himself.

(Qur'ān, 92:18)

The Qur'ān, recommends the Prophet Muhammad (may the peace and blessings of Allah be upon him) as the ideal model for our behavior. The generosity of our Prophet Muhammad (may the peace and blessings of Allah be upon him) is well known. He never turned away anyone who sought his help.

It is narrated by Ibne-Abbas that the Prophet (may the peace and blessings of Allah be upon him) was the most generous of all the people, and he used to become more generous in Ramadan when Gabriel met him. Gabriel used to meet him every night during Ramadan to revise the Qur'ān with him. Allah's Messenger (may the peace and blessings of Allah be upon him) then used to be more generous than the fast wind. (al-Bukhari, 1422H, 1:8, hadith no. 6)

The Prophet (may the peace and blessings of Allah be upon him) had compassion, concern, and mercy:

Indeed, there has come unto you [O mankind] an Apostle from among yourselves: heavily weighs upon him [the thought] that you might suffer; full of concern for you [is he, and] full of compassion and mercy towards the believers. (Qur'ān, 9:128)

He was "mercy to all mankind", not just the believers (Qur'ān, 21:107). The Qur'ān chides him, saying do not kill yourself with sorrow, on behalf of those who do not believe in your message (Qur'ān, 18:6). This shows his extreme compassion and sympathy for the suffering of others including even animals.

The solution to the problems of poverty lies in emulating the example of Umar Farooq (may Allah be pleased with him), who was eating coarse bread. When asked why, he said that he felt embarrassed to eat refined bread when not everyone in the ummah could afford to eat it (Ibn al-Sary, 1985, 2:364). If the wealthy consider this wealth to be a responsibility and a trust which has been given to them because of the poor, then they will recognize the rights of the poor in their wealth. Instead of flaunting their wealth in the face of the poor, they will share excess wealth 
with those in need. These are essential and core elements in the Islamic approach to poverty which have no counterparts in the Western approaches.

\subsection{Learning to Respect and Honor Piety Alone}

Dignity, honor and respect are to be accorded to the person as per his/her degree of closeness to Allah (piety or taqwá), and not by conventional standards of wealth and standing in the community. When judging two people, the Prophet Muhammad (may the peace and blessings of Allah be upon him) taught the companions that the poor and socially inferior person with taqwá had more dignity and honor in the eyes of Allah than a planet full of rich and rebellious persons (derived from, al-Bukhari, 1422H, 8:95, hadìth no. 6447). The Qur'ān also affirms that:

O mankind! We created you from a single (pair) of a male and a female, and made you into nations and tribes, that ye may know each other (not that ye may despise each other). Verily the most honoured of you in the sight of Allah is (he who is) the most righteous of you. (Qur'ān, 49:13)

A capitalist society makes the pursuit of wealth the most important goal and accords honor only to those with wealth. In particular, the value of human lives is calculated according to the present discounted value of earnings so that the poor have very low value compared to the rich. Islam creates a radical and revolutionary change in perspective. Throughout Islamic history, scholars and Sufis have been accorded far greater honor, popularity, and respect than that commanded by the wealthy and the powerful. However, these values are undergoing change in Islamic societies currently due to the powerful onslaught of modernity.

Providing the poor with lives of dignity and honor is central to the Islamic approach to dealing with poverty and inequality. The rich are told to give to the poor without offending their dignity (Qur'ān, 2:262). They are also told that they have been given their wealth by Allah because of the poor among them, and also that the poor are entitled to a share of their wealth (Qur'ān, 70:24). Those who have in excess of their needs are given the responsibility to take care of those with less. Furthermore, the poor are told to conceal their needs and ask only from Allah, while the rich are told to seek out the needy and help them (Qur'ān, 2:273). As Imam Ghazali writes, the rich should not feel superior while giving to the poor; instead, they should feel grateful that they have been given the opportunity to perform an act of worship leading to purification of the heart, due to the presence of the poor (al-Ghazali, 2005, 1:257).

The idea that the wealthy are given wealth for the sake of the poor, the strong have been given strength to protect the weak from oppression, and those who have been given control are responsible for the wellbeing of those under their command is a revolutionary reversal of standard attitudes. Some aspects of this are expressed in a hadīth which states that:

All of you are shepherds and each of you is responsible for his flock .... (al-Bukhari, 1422H, 9:62, hadìth no. 7138)

As recent research reveals (see, for example, Sen, 2000), social exclusion is a very important dimension of poverty, neglected in simple-minded approaches which view poverty as merely a lack of money. Since most of the poor must labor for a living, Islam pays great importance to the dignity of labor. The Holy Prophet (may the peace and blessings of Allah be upon him) said:

Your brothers are your servants whom Allah has made your subordinate, he should give them to eat from what he himself eats and wear from what he himself wears and do not put on them burden of any labor which may exhaust them. And if you have to put such burden on them, then help them with it. (al-Bukhari, 1422H, 1:15, hadìth no. 30)

As the hadith states, equality in lifestyle (clothing and food) is preferred for superiors and subordinates. One of the great divides among the haves and have-nots in capitalist society is the idea that the owner or boss is superior to the workers. Instead, Islam views all engaged in production as partners in a joint enterprise. Islamic economists have stated that the concept of a labor-managed firm is in accord with Islamic conceptions of work organization. Some more reflections on dignity of labor created by Islamic ideals will be discussed later. This aspect is crucial and central to the alleviation of the trial of poverty in Islamic societies. 


\section{The Social Dimension}

Whereas economists have understood poverty to be merely a lack of money, recent research has established that poverty is a multi-dimensional phenomenon which cannot be addressed simply by throwing money at $\mathrm{it}^{(10)}$. The inner spiritual dimension has been addressed in the previous section. In this section, we will discuss how Islam addresses the issues of inequality and poverty in context of the social dimension. Islam places heavy emphasis on unity, brotherhood, and love of humanity as the basis for building a society. This naturally leads to the creation of well-knit communities. At the heart of society is love and compassion for all humanity embodied in the character of our Prophet Muhammad (may the peace and blessings of Allah be upon him). This is the base on which the ties of kinship and community are forged and the ummah is united for the purposes of seeking the welfare of all humanity. These four levels are discussed below.

\subsection{Mercy to The Nations}

At the core of building any society is the love that binds the members together. The Prophet Muhammad (may the peace and blessings of Allah be upon him) was sent as a perfect model, to provide a living illustration of ideal behavior in this regard. As the Qur'ān states:

We have not sent thee, except as a Mercy to all creation. (Qur'ān, 21:107)

The Qur'ān testifies to the compassion of the Prophet (may the peace and blessings of Allah be upon him), saying "Grievous is your suffering to him" (Qur'ān, 9:128). It also testifies to the pain felt by the Prophet (may the peace and blessings of Allah be upon him) on the behalf of all mankind as they would come to a bad end if they did not heed his warnings and accept his glad tidings:

perhaps you would kill yourself through grief over them, [O Muhammad], if they do not believe. (Qur'ān, 18:6).

$\mathrm{He}$ is reminded that he is not responsible for their guidance and that he has fulfilled his duty to convey

(10) Brief introduction and guides to vast amounts of theoretical and practical research on multidimensional poverty are available from http://ophi.org.uk, the website of Oxford Poverty and Human Development Initiative. the message in the best of ways, with kindness, courtesy, and respect. The entire ummah (the group of Muslims), is told to follow his example in this regard. The Muslims are charged with the responsibility of taking the message of God to all. This message includes the brotherhood of man and the necessity of loving all human beings as our brothers. As stated in a hadith: "the Believer loves and is loved" (al-Shaibani, 2001, 15:107, hadith no. 9198; al-Tabarani, 1995, 6:58, hadīth no. 5787)

Islamic source materials contain many practical recommendations to create love and unity. For instance,

- Make peace between brothers.

- Give up on arguments to make peace.

- Give others their rights and do not be concerned about getting your own rights.

- Give more than fair share to others.

As discussed earlier, the vision of a society as an organic whole was lost in the transition to modern market societies in Europe. In contrast, Islam came to Arabs who were divided into warring tribes and united their hearts to create a community of Muslims. The first act of the Prophet (may the peace and blessings of Allah be upon him) on arriving in Madinah was to create brotherhood between the immigrant Muhajireen and the resident Ansar. He also took steps to eradicate the traditional rivalries between the resident tribes and to unite their hearts on Islam. He also created the pact of Madinah for fair and equitable dealings with other non-Muslim communities residing in Madinah. The Qur'ān testifies that all the treasure in the world could not have purchased this unity:

$\mathrm{He}$ it is who has strengthened thee with His succour, and by giving thee believing followers whose hearts He has brought together: [for,] if thou hadst expended all that is on earth, thou couldst not have brought their hearts together [by thyself]: but God did bring them together. Verily, $\mathrm{He}$ is almighty, wise. (Qur'ān, 8:62-63)

Whereas poverty and inequality are social problems in a capitalistic society, they are tools to build community in an Islamic society. This is more or less explicitly stated in the verse $(43: 32)$ of the Qur'ān 
cited earlier. Inequalities and poverty create dependencies and complementarities where each person has something that others need and also has needs for which he must turn to the community. This network of needs and dependencies acts as a lubricant in the creation of cooperation and community.

This should be contrasted with the Hobbesian notion of society as a war of all against all. This is the notion that underlies the modern nation-state. Evolutionary theories treat society as a jungle, whereas Islam teaches us to use cooperation and love as the building blocks of society.

The European experience has been bitter in this regard. Centuries of warfare has led them to regard the state of war as natural. This mindset is reflected in both fictional and intellectual productions. HG Wells' War of the Worlds, Star Trek, and numerous other fictional works take for granted that when two civilizations meet, it will always be on hostile terms. Similarly, when Huntington wrote "The Clash of Civilizations", the blueprint for western war against the Islamic civilization, the idea that civilizations could peacefully co-exist and have mutually beneficial interactions did not occur to him. A major cause of poverty around the world is the creation of hostileties leading to small and large wars which brings great profits to the military-industrial complex. Measures to increase spirituality, which creates compassion for others, could contribute greatly to the alleviation of suffering caused by poverty. See Zaman's (2017) lecture on Spirituality and Development for an extended discussion.

\subsection{Community}

Close ties with family and kinfolk, and strong neighborhood communities are essential building blocks of Islamic societies. These are also the most important tools which protect against difficulties arising from inequalities and poverty.

The keys to building community are forged in the bosom of a warm and loving family, where the children are nourished, nurtured, and trained to overcome selfish tendencies and fulfill social obligations. The Prophet Muhammad (may the peace and blessings of Allah be upon him) was a model of love, kindness, as well as respect for children, and placed great emphasis on these qualities saying that those who do not love children are not from us (see al-Tirmidhi, 1975, 4:321, hadith no. 1919). It is this love and nurturing received by children in their families which creates the strong bonds of kinship; which receive extreme importance in Islamic teachings. We are told to make connections with family even though they may cut ties with us. Good treatment towards kin, regardless of whether or not they are Muslims, is prioritized. The Qur'ān has many verses detailing and emphasizing the rights of the extended family. For instance:

And worship Allah, and do not associate anyone with Him and do good to parents, and to relatives and orphans, and the needy, and the near neighbor (relatives) and the distant neighbor (non-relatives) and the companion of your side and the wayfarer. (Qur'ān, 4:36)

Growing out ties to the family comes the second natural community, which is the neighborhood. Close ties with neighbors are an essential component of Islam. The rights of neighbors were emphasized so much that the Prophet Muhammad (may the peace and blessings of Allah be upon him) stated that he thought the neighbors might be given the rights to inherit our properties (al-Bukhari, 1422H, 8:10, hadith no. 6014). The Holy Prophet (may the peace and blessings of Allah be upon him) stated that:

That man has not believed in me who sleeps contentedly while his neighbor sleeps hungry. (alTabarani, 1994, 1:259, hadìth no. 751)

Similarly, he also stated:

Do you know what are the rights of neighbors? Help them when they need your help, give them loans, if they are poor, spend upon them, if they are sick, visit them, if they are happy, greet them, and if they are sad, share their sorrow, if they die, participate in their funeral, . . . I swear in the name of the One in Whose custody is my life, no one fully fulfills the rights of neighbors except very few among you upon whom Allah showers His Mercy. (al-Bayhaqi, 2003, 12:104, hadìth no. 9113).

Similarly, Zain al-'Abideen, Ali bin al-Husain, in his Risalat al-Huquq, said:

These are your duties towards your neighbor: Protect his interests when he is absent; show him respect when he is present; help him when he is inflicted with any injustice. Do not remain on the look-out to detect his faults; and if, by any chance, you happen to know any undesirable thing about 
him, hide it from others; and, at the same time, try to desist him from improper habits, if there is any chance that he will listen to you. Never leave him alone at any calamity. Forgive him, if he has done any wrong. In short, live with him a noble life, based on the highest Islamic ethical code. (Treatise on Rights [Risalat Al-Huquq], para 32, The Right of the Neighbour)

The existence of a community acts as a major bulwark against poverty. The neighborhood mosque provides a concrete institutional building block for construction of community by gathering all males together five times daily. Many authors have documented the dissolution of communities in the West as a result of economic pressures and of economic theories which completely ignore and neglect the vital role that communities play in societies (see, for example, Marglin, 2008). The pressures of modernity are having the same effect in the Islamic world. In the fight against poverty, a key element would be the preservation of families and communities against the onslaught of modernity which strips individuals of the protection provided by community.

The dominant Western conceptions of society are the Hobbesian and Darwinian view of society as a war of all against all, or the jungle ruled by cut-throat competition leading to the survival of the fittest. In economic theory, firms achieve efficiency by battling for survival in a competition to maximize their profits without concern for social welfare. Similarly, greedy individuals seek to maximize their lifetime consumption without any concern for others. In such a world, inequality is a threat since it gives wealthy the power to exploit the rest. In the Islamic conception of humanity as a brotherhood, and community as close kin, a rich and powerful relative is a source of comfort rather than a threat. In times of need, we can count upon their support. Strong ties of community and mutual responsibility, emphasized by Islam, change the role and function of poverty and inequality.

The modern world created by the great transformation highlights individualism, pursuit of pleasure, and competition. In this world, self-sufficiency is essential since we cannot rely on the support of others, not even of close family. Similarly, inequalities lead to conspicuous consumption and envy. In contrast, in Islamic societies, inequalities and poverty create mutual dependencies which make creation of communities easier as explained in the opening verse (Qur'ān, 43:32). Islamic teachings tell us to fulfill our social responsibilities so that those with excess wealth take care of those in need. As long as wealth circulates freely within the community, as commanded by the Qur'ān, inequalities and poverty are social lubricants which are helpful in creating communities.

\subsection{Ummah}

Islamic teachings lay heavy stress on uniting the hearts of the Muslims and on creating a community of believers:

And, verily, this community of yours is one single community, since I am the Sustainer of you all: remain, then, conscious of Me! (Qur'ān, 23:52)

Warring tribes with deep enmities embedded in century-old traditions were united as brothers by the advent of Islam.

And hold fast, all together, by the rope which Allah (stretches out for you), and be not divided among yourselves; and remember with gratitude Allah's favor on you; for ye were enemies and He joined your hearts in love, so that by His Grace, ye became brethren. (Qur'ān, 3:103)

According to a hadith, this ummah is like one body. If any part is hurt, the whole body feels the pain (alBukhari, 1422H, 8:10, hadith no. 6011). This creation of unity, of the sense of mutual responsibility for each other, is central to Islamic concepts for solving the problems of the weak and oppressed. The provision of basic needs to all is the collective responsibility of the ummah as a whole. In particular, education, health, and social welfare of all the children in the ummah is our collective responsibility. Collective responsibility (fard al-kifāyah) is discharged by everyone participating in doing their own share. Thus, every local neighborhood community takes care of its members, families take care of their own, and those with excess take care of those who do not have sufficient means. Historically, for over a thousand years, these functions were performed superbly in the Islamic civilization using a collection of institutions (to be discussed later) motivated by the desire for earnings in the hereafter. Education was freely available to all who sought it (see Shalaby, 1954).

The concept of charging money for health and education, natural to a market economy, was alien to 
Islamic conceptions of the structure of social responsibilities. Those with knowledge were given the responsibility to convey this treasure to those without. People learned the skills of health sciences in order to earn the reward promised in the Qur'ân that he who saves a life, it is as if he has saved the whole world (Qur'ān, 5:32). The money required for these functions was made available by a variety of private and public means, fueled by the strong Islamic injunctions for generosity and charity.

\subsection{Humanity}

The message of the Qur'ān is addressed to humanity as a whole:

O Mankind, We created you from a single (pair) of a male and a female and made you into nations and tribes, that you may know each other. Verily the most honored of you in the sight of God is he who is the most righteous of you. (Qur'ān, 49:13)

The Prophet Muhammad (may the peace and blessings of Allah be upon him) is described as the mercy of God to all of creations (Qur'ān, 21:107). Despite appearances to the contrary, created both by media and by certain extremist groups of Muslims, the central message of Islam is not to unite the Muslims against the non-Muslims. Quite the contrary, the message of Islam is to unite all of humanity under the banner of the best ideals in the common heritage of mankind:

You have become the best of communities, raised for the (benefit) of mankind. (Qur'ān, 3:110)

Historian Marshall Hodgson (2009) has expressed the effects of this injunction to create welfare for mankind in the following terms:

Soon after the founding of the faith, Muslims succeeded in building a new form of society, which in time carried with it its own distinctive institutions, its art and literature, its science and scholarship, its political and social forms, as well as its cult and creed, all bearing an unmistakable Islamic impress. In the course of centuries, this new society spread over widely diverse climes, throughout most of the Old World. It came closer than any had ever come to uniting all mankind under its ideals. (p. 71)
The tolerance, open-mindedness, and lack of prejudice in Islamic civilization has been attested to by numerous authors. There is no compulsion in religion and Muslims are told that they only have the duty to carry the message to others:

It is not for thee [O Prophet] to make people follow the right path, since it is God [alone] who guides whom He wills. (Qur'ān, 2:272)

The unique live-and-let-live attitude of the Qur'ān is embodied in several verses and in the lives of the Prophet Muhammad (may the peace and blessings of Allah be upon him) and his companions. For instance, the Qur'ān states:

Verily, those who have attained to faith [in this divine writ], as well as those who follow the Jewish faith, and the Christians, and the Sabians - all who believe in God and the Last Day and do righteous deeds - shall have their reward with their Sustainer; and no fear need they have, and neither shall they grieve. (Qur'ān, 2:62)

The effects of these teachings of broad-minded tolerance, of the equality and brotherhood of man, are evident throughout the history of Islamic civilizations. For instance, Maria Rosa Menocal (2002) describes how the Muslim rulers of Spain created a culture of tolerance in Spain where Christian and Jewish scholars, philosophers, and religious authorities freely inter-mingled and enriched society by their diverse contributions. Similarly, historian Arnold Toynbee (1948) writes that "The extinction of race consciousness as between Muslims is one of the outstanding achievements of Islam, and in the contemporary world there is, as it happens, a crying need for the propagation of this Islamic virtue" ( $p$. 205). The impact of these radical teachings of universal brotherhood of man - our responsibilities for excellence in conduct, equality - continue to reverberate throughout the world. See, for example, The Enlightenment Quran by el-Marsafy (2009), which documents the tremendous impact of the translations of the Qur'ân on the leading enlightenment philosophers in Europe. Similarly, Spellberg (2013) documents the effects that Thomas Jefferson's reading of the Qur'ān had on the framing of the US Constitution. 


\section{Institutional and Regulatory Dimension}

Spiritual and social arrangements must be supplemented by complementary institutional and legal frameworks in order to have an effective impact on real-world problems. In the past, Islamic societies created a rich fabric of institutional structures to take care of problems related to social welfare. Secular societies, framed around the concept of conflicting communities, lack the capacity for local collective action. Thus, public welfare must be relegated to the government; an attitude which has now also been adopted in the Islamic world. Historically, in Islamic societies, communities are united in purpose and hence action can be delegated to the community level. This is how social welfare was managed throughout the Islamic civilization for more than a thousand years.

The institutional and legal structure represents ethical and moral commitments of a society. Islam has a deep-seated commitment to equality for all, not in terms of wealth, but in terms of opportunities. We discuss this further by considering the following points.

1. Equal opportunity for all.

2. Waqf, zakāh, șadaqāt.

3. Guilds, service orientation, markets and market regulation.

4. Regulatory and legal framework.

\subsection{Equal Opportunities: Education and Jobs}

As discussed earlier, a Muslim society has a collective responsibility for the basic needs of all its members, including health, education, food, housing, and provision of opportunities for employment. However, the mechanisms for achieving this goal differ radically from those of contemporary secularized market societies. Since secular societies are composed of individuals pursuing separate and conflicting goals, the only possible agent for collective action is the government. Accordingly, nearly all major social welfare activities are relegated to the government. In contrast, Islam makes the provision of basic needs a collective responsibility (fard alkifāyah) for society as a whole. This concept of collective responsibility has been listed by Syed Abul Hassan Ali Nadvi (1986) as among the important contributions that Islam has made to world civilization. Fard al-kifäyah creates an expanding circle of responsibilities for individuals and institutions functioning within a society. In the first instance, every individual is responsible to look after his own needs. His providing for his own person and for those who fall within his social responsibility such as his family, elders, and other needy kinfolk, is regarded as a form of worship. To the extent that a particular family or community is unable to look after itself, it falls to the larger communities to look after them. All those with resources in excess of their needs are collectively responsible for those who do not have sufficient resources $^{(11)}$. The government is responsible as a last resort when combined community resources do not suffice for the task.

Recognition and fulfillment of these responsibilities go back to the earliest times of Islam. The second Khalifa of Islam, Umar (may Allah be pleased with him) said to a non-Muslim citizen who had paid taxes when young that he was entitled to be provided for in old age (Abu Yusuf, 1979, p. 126). The first state-run hospitals and orphanages, as well as pensions for widows, the handicapped and older people, were established in his time. Khalifah Umar bin Abd al Aziz is reported to have wept with the worry that he was responsible for and would have to answer to God about "the hungry, the poor, the unattended sick, the prisoner in alien lands, the very old, those with many dependents but little money, and similar people" (Ibn al-Atheer, 1997, 4:119). If resources are inadequate to meet all the needs, then the community must prioritize according to the guidelines prescribed by the Sharī'ah. As a last resort, a community may pool its resources and share them equally. It is narrated that Umar (may Allah be pleased with him) said:

If I had no money left to feed the people, and the only way left was to make all households share their provisions with an equal number, with everyone being only half fed till Allah gave us rain, I would have done so. For men could still survive on only half the food they need. (Ibn Sa'ad, 1968, 3:316)

(11) Consider the dramatic contrast with radical liberal conceptions of individual freedom; one of its leading advocates, Gauthier (1986) writes "The rich man may feast on caviar and champagne, while the poor woman starves at his gate. And she may not even take the crumbs from his table, if that would deprive him of his pleasure in feeding them to his birds" (p. 218). 
It is worth noting that the motives for provision of economic security in an Islamic society are radically different from the utilitarian or Rawlsian principles within a secular society. A primary objective is the creation of goodwill and harmony in order to build a community. In addition, economic security also frees individuals to turn to higher spiritual and social pursuits. Two aspects of economic security deserve to be highlighted as they are the key to provision of equal opportunity which is an integral component of Islamic society. These are education and labor.

\subsubsection{Education}

Among the basic needs, education deserves special attention. It is the route to equal opportunity. It also plays a special role because it is an excellent channel through which the collective responsibility of the state and citizens to provide for people's moral development can be fulfilled. Islamic teachings place extremely high importance on education. Since providing education to the young is a collective responsibility of society, there was no concept of charging money for this. For all who desired it, education was freely available. This provided for equal opportunities for all in a way that has rarely been matched. Shalaby (1954) gives a history of educational methods, syllabi, institutions, libraries, the inclusion of women, and other evidence of the prevalence of education in the first 600 years of Islamic civilization. Equal access to education via $a w q \bar{a} f$ and the general respect for learning in Islamic societies led to representation of all social classes within their intellectual elites. Kahf (1992) cites al-Syed (1989, pp. 237-258) as stating that "at times, majority of Muslim scholars used to be coming from poor and slave segments of the society and very often they strongly opposed the policies of the rulers" (Kahf, 1992, p. 10).

A major source of poverty and inequality today is the lack of access to equal opportunities to education, both in Islamic societies and globally. In a market society, every good is for sale. Even where public schools exist, the elite can purchase higher quality education. A shining counter-example is Finland which crafted an educational policy on the basis of a single principle: every child should have access to exactly the same educational opportunities ${ }^{(12)}$. This is

(12) See: Finnish education in a nutshell: "One of the basic principles of Finnish education is that all people must have very Islamic in concept and is probably the single most important innovation required to remove the inequities associated with poverty. In general, European countries with socialized health and educational systems do much better on providing equal opportunities. Purely capitalist and market-oriented economies like the USA do very poorly, where extreme inequalities in educational opportunities create a lack of social mobility and hence poverty is transmitted from generation to generation. Islamic countries have generally imitated capitalist models and failed to provide alternatives based on institutional structures from pre-colonial times.

Even more important than the failure to provide equal educational opportunities is the failure to provide the right kind of education. In a capitalist economy, education is valued only as a means to earning money. In Islam, an education develops character, teaches social responsibilities, virtues, and trains the mind, heart, and soul. Some aspects of this broader multi-dimensional training were present in Western educational curricula in the early $20^{\text {th }}$ century. However, as detailed by Julie Reuben (1996) in The Making of the Modern University: Intellectual Transformation and the Marginalization of Morality, all such elements were gradually removed and education came to mean purely technical training required to make a living. This has led to a dramatic loss of character so that graduates of the finest schools in the West commit mass murders without moral qualms ${ }^{(13)}$. In the East, the same educational trends are being copied with equally disastrous results. The missing spiritual dimension leads to a lack of sympathy and compassion, which is an important driver of poverty (see Zaman's 2017 lecture on Spirituality and Development).

\subsubsection{Labor as Worship}

The Qur'ān places extremely great value on human lives:

whoever saves one (life), it is as if he had saved the entire mankind. (Qur'ān, 5:32)

equal access to high-quality education and training. The same educational opportunities should be available to all citizens irrespective of their ethnic origin, age, wealth or where they live" (p. 6) (http://www.oph.fi/download/ 146428_Finnish_Education_in_a Nutshell.pdf)

(13) See David Halberstam (2002) or David Glover (2001). 
The moments of our lives are so precious that all the gold in the world would not suffice as ransom for one extra moment of prolongation of life. Given that lives cannot be bought or sold for money, Islamic methods for production of goods and utilization of labor are radically different from those of capitalist labor markets. Unfortunately, the prophecy that "Islam came as a stranger, and will become a stranger" (alNaisabouri, 1991, 1:130, hadith no. 145), has come true. The norms of the marketplace have taken such deep roots in Islamic societies that the original Islamic concepts have been lost and forgotten.

In market societies, capitalists produce goods for profits and purchase inputs for use in the production process. As Marx noted, time of the laborer is purchased, just like other commodities and inputs used in the production process. This leads to "alienation", where the laborer loses the right to control his life and destiny, entitlement to the goods he produces, and connections with society, and is denied the right to meaningful work (Marx, 1959). In principle, both according to economic theory and also according to how markets operate, he is an interchangeable part in the production process.

Islam considers human lives as infinitely valuable, precious beyond the possibility of purchase, and unique. As specified by many scholars, it is selfevident that in Islam the fundamental problem of man is not economic, and economic progress is not a goal or objective of life for humans (Shafi, 1979, p. 4). In the Holy Qur'ān, Allah Almighty asks us to sell our lives and property to buy the infinite rewards of paradise (Qur'ān, 9:111). Contracts involving sale of significant portions of our lives for finite material gains on this Earth make no sense. This perspective requires a radical re-conceptualization of labor and its use for production of goods and services. In particular, man has been created only for the purpose of worship (Qur'àn, 51:56), so it follows that the only acceptable forms of labor must be performed as acts of worship. We now discuss how Islamic principles are used to accomplish this transformation.

In-line with the secondary status of economic activity in Islam, earning to support yourself and all for whom you are responsible is a religious duty, though it is of lesser priority than primary religious duties like the five pillars of Islam. Thus, if we work to feed ourselves and family, this is a form of wor- ship. This Islamic concept of labor is differentiated from the compulsion to work out of economic necessity that is required for the function of capitalist societies in many important ways.

The requirement for labor is only up-to adequacy - that is we work to provide a comfortable living but earning more than required, in order to allow for conspicuous consumption and to flaunt our wealth, is not permitted.

Capitalism, which requires ever-increasing levels of production, is built on creating excess desires for consumption and creating excess production to match these artificially created desires ${ }^{(14)}$. This would not be permissible in an Islamic society, where simple lifestyles are preferred to houses of gold and silver.

Because of Islamic commands for simple lifestyles without ostentation or conspicuous consumption, we would expect that GNP per capita in Islamic societies would be lower than that in capitalistic societies. The main purpose of life is not production and consumption. Indeed, as many critics of consumption have noted, the rat race of artificially generated production-consumption cycles prevents us from enjoying those aspects of life which really contribute to happiness. For example, David George (2001) writes about how markets pollute our preferences and create desires that harm our welfare. The social goods, community, family, friends, sports, and sociallization are free goods which require time and effort not available due to the pressure of keeping up with ever-increasing standards of living. As a result, people in hospices express regrets over having neglected friends and family in the pursuit of career and wealth (see Ware, 2011).

Even though production of useless products would be reduced, Islamic societies are not ascetic and useful services and products would be plentiful and efficiently produced. Efficiency in production is created by the conception of labor as a worship. "Shirking", a common problem when labor is performing an unpleasant chore, would not arise as violations of contractual agreement to work by reducing efforts render the income harām. At the same time,

(14) See for example Julie Schor (1999), for how consumer culture makes people desire to purchase what they don't need and how deliberate steps to simplify and downshift can improve our lives. 
the need to labor for a living would be reduced providing more time for higher spiritual and social pursuits. The Islamic framework for labor and production is organized on the basis of principles entirely different from those of a capitalist society.

Studies of human motivation show that people enjoy working and find it meaningful for many reasons very different from the financial benefits of work. Islamic firms are required to treat workers with dignity and respect, and equality maintained between employers and employees in terms of their social status (in particular, clothing, housing, and food). Islamic theory sees the employer and employee as engaged in a cooperative enterprise to provide valuable goods and services to the society. Within this framework, all work becomes meaningful as it is a form of worship to provide service to human beings. Even a menial worker cleaning a mosque feels that he is making a valuable contribution to social welfare. Capitalist purchase of labor, driven by needs and by addiction to artificially high standards of living, creates anomie and alienation and leads to a feeling of lack of purpose and a lack of dignity which is among the deep deprivations created by poverty. In capitalist systems, work is an unpleasant duty compensated for by money. This leads to problems of shirking and monitoring. By turning work into worship, Islam provides us with the tools to tackle and overcome these problems even though these solutions currently exist only in books of Islamic history.

\subsection{Zakāh, Șadaqāt and Awqā f}

In order to impact the real world, the spirit of generosity, compassion, and responsibility, strongly embodied in the teachings of Islam, must be given concrete expression in the form of institutional structures for implementation. Most important among these structures are, zakāh (obligatory charity), șadaqāt (voluntary charity) and awqāf (institutional charity for long-term purposes).

One of the five pillars of Islam, zakāh is a means of self-purification for the wealthy and also an institutional means for fulfilling our collective responsibilities towards the poor. Historically, it has been a powerful tool for the relief of poverty. Colonization destroyed functional systems for provision of social welfare throughout the Islamic lands and created peripheral capitalist institutional struc- tures designed to be dependent on the core. These institutions, which reflect the capitalist spirit of accumulation of wealth without purpose, conflict with Islamic values and have hindered the return to precolonial methods for providing social welfare. Whereas zakāh was previously collected by the government and utilized efficiently for public welfare, it has now been reduced to random and ad-hoc private acts of charity. However, there has been increasing recognition of the potential of zakāh as a basis for creating systematic and deep-rooted long-run solutions to poverty; see for example, the Bangladesh initiative of Center for Zakat Management ${ }^{(15)}$.

Whereas the spirit of capitalism is the accumulation of wealth, the Islamic spirit is to spend excess wealth on others:

...They ask thee how much they are to spend; Say:

"What is beyond your needs". (Qur'ān, 2:219)

The Prophet (may the peace and blessings of Allah be upon him) recommended those with excess wealth to set up institutions which would devote revenues to specified charitable purposes, thereby earning rewards in perpetuity. Historically, $a w q \bar{a} f$ were the central vehicle for provision of social welfare in Islamic societies. It is estimated that about one-third of the land in the Ottoman Empire was devoted to such trusts (Kahf, 1992, p. 9). The awqāf formed the basis for a rich and vibrant civil society and shaped the urban space. A major part of the public environment in Islamic towns actually came into being as a result of endowments. Sait and Lim (2006) write that the system of $a w q \bar{a} f$ "succeeded for centuries in Islamic lands in redistributing wealth" (p. 156), leading to equitable outcomes and the circulation of wealth in accordance with Qur'ānic injunctions. In particular, these $a w q \bar{a} f$ provided adequately for social needs on a community-centered and community-driven basis to the extent that the Ottoman Khalifas did not see themselves as being responsible for the provision of social services to the population. Thus, these institutions form a historically proven Islamic alternative to the current European welfare state model for providing for people's needs. The Islamic methodology has two distinct advantages:

(15) http://czm-bd.org/history 
- The awqāf were locally based and managed. They had substantially more local information than state-run systems typically do, and could, therefore, perform more efficiently.

- The Islamic requirement that social institutions should inculcate a sense of responsibility, reinforce social ties, and increase social awareness was also fulfilled by this system.

There is today widespread agreement among Muslims on the need to revive the institution of waqf and give it the central importance that it had in the past. Sait and Lim (2006) discuss some of the required reforms noting that Kuwait has taken a lead in this area.

\subsection{Islamic Business Models}

Islam places great emphasis on business as a means of earning a living. According to a hadith, the honest trader ranks with the martyrs, saints, and prophets (alTirmidhi, 1975, 3:507, hadith no. 1209). This is because trade, done according to Islamic principles, is a triple act of worship. In standard Western models, the sole object of business is to make profits, and provision of service is a means to this goal. However, Islamic business models reverse this relationship. The goal of an Islamic business is to provide service to the community, and the making of profits is a means to sustain this provision. When money is earnt with the intention of spending it for the sake Allah (for any goal permissible in the Sharīah) in obedience to the following verse of the Qur'ān, then it becomes an act of worship:

But as for all who lay up treasures of gold and silver and do not spend them for the sake of God give them the tiding of grievous suffering [in the life to come] ${ }^{(16)}$. (Qur'ān, 9:34)

A Muslim businessman earns money to provide for his own and his family's needs which is an act of worship. He also earns to provide jobs, providing

(16) The Qur'ān is aligned with traditional views, dating back to Aristotle, that wealth is a means to an end, and not an end to be sought for itself. As opposed to this, a market society, created by the Great Transformation, makes wealth a goal. For example, Max Weber (1930) writes that the spirit of capitalism is "the earning of more and more money ... as an end in itself ... appears entirely transcendental and absolutely irrational. Man is dominated by the making of money, by acquisition as the ultimate purpose of his life" (p. 53). both a service to the community and livelihoods to employees. In addition, the business itself provides products and services to human beings; this is an act of worship and a source of blessings. According to a hadith "The provider (of services or goods) is blessed" (Ibn Majah, 2009, 3:282, hadìth no. 2154).

Making service, instead of profits, the goal of business creates a model radically different from those currently being taught in MBA programs in leading universities and imitated globally. Western theories of the firm have taken a dramatically dangerous turn, allowing the search for corporate profits to destroy millions of lives and threatening to destroy the planet ${ }^{(17)}$. The corporation has been granted autonomy, the same rights accorded to human beings, but no responsibilities (see Parkinson, 1995). The idea that human individuals have 'freedom of speech' has been applied to provide corporations with the right to make arbitrarily high campaign contributions to congressional representatives (see Epps, 2011), effectively allowing them to bribe the government. Many authors have documented the stranglehold of corporate power over governments all over the world (Korten, 2015).

Instead of the profit motive, Islam offers the service motive as the driving engine behind firms. This leads to radical changes in the theory of the firm. Whereas profit-making firms will pollute, cause environmental damage, lobby for sale of unsafe products and drugs, and charge extortionate prices for necessary products, service-oriented firms will not engage in such behavior. The service motive turns the running of the firm into an act of worship, but also creates a heavy burden of responsibilities not faced by the profit-making firm. The bottom line of the serviceoriented firm is the amount of service provided to humanity, where any externalities, collateral damage to environment and society, and harm caused to workers, all must be figured in. Studies of Islamic businesses - guilds in Islamic Spain and in the

(17) Harvard MBA professor Zuboff (2009) writes that "I spent a quarter-century as a professor at the Harvard Business School, including 15 years teaching in the MBA program. I have come to believe that much of what my colleagues and I taught has caused real suffering, suppressed wealth creation, destabilized the world economy, and accelerated the demise of the $20^{\text {th }}$ century capitalism in which the U.S. played the leading role" (Business Week, Viewpoint, July 2, 2009). 
Ottoman empire - show their responsible behavior and their charging prices to generate a fair profit (around 10\%) rather than what the market would bear (see Zarinebaf, 2007). This may be compared with big pharma which charges enormous prices for lifesaving drugs creating billions in profits on the pretense that this is essential for the research that they do. Placing the burden of healthcare on the poor, combined with overpricing of essential healthcare, is a characteristic of capitalism which creates the most difficult problems for the poor around the world.

\subsection{Legal and Regulatory Framework}

The central theme of Polanyi (1944) is not that markets harm societies, but that unregulated markets cause massive damage to society. In this context, the institution of hisbah for regulation of markets goes back to the Prophet Muhammad (may the peace and blessings of Allah be upon him). Economic theory recognizes damages to society caused by profitseeking behavior of firms and calls this "market failure". In Islam, firms are discouraged from this kind of irresponsible behavior, and regulatory and legal mechanisms are created to ensure compliance. Naz (1999) gives a comprehensive survey of hisbah, which includes a wide-range of responsibilities for public welfare. The semi-judicial institution of alhisbah, operational from the earliest days of Islam, is charged with the responsibility of setting conditions that preserve and enhance the public health and interests, protect the consumers, solve business and labor disputes, promote good market behavior and ensure their observance. In the realm of the marketplace, the hisbah ensured that weights and measures were of official standard; provided stamps of quality; ensured that goods being sold were of standard quality by various means; took actions against false advertising, hoarding to increase prices, collusion and monopolistic actions; and generally protected the public interest. Issues like pollution of rivers or the environment also fall under the jurisdic-tion of the hisbah. An examination of these different roles and their implementation in different periods of Islamic history is given in Chapter 5 of Naz (1999).

The main issue of note is the insight presented in the Logic of Collective Action by Mancur Olson (2009). In areas where a few people can combine to act collectively and gain great benefits, they can take actions to damage the public interest where a large group, each of which suffers a small loss, cannot easily combine to protect their collective interests. This allows the $1 \%$ to exploit the $99 \%$ and is a source of a great variety of loss and damage to the public. It exacerbates problems created by poverty. Islam provides an effective remedy in the form of an institution designed to protect the collective interests of the weak and the oppressed.

\section{Concluding Remarks}

Recent research reveals that poverty is a multidimensional phenomenon consisting of deprivations in many dimensions of life. Current mainstream approaches focus too narrowly on the money dimension and neglect vital social and spiritual aspects, which can be both part of the problem and part of the solution. One extremely important aspect which is routinely neglected is power. Contemporary economic systems provide privileges to the super-rich which cannot be dreamt of by the bottom $90 \%$. This enables and empowers them to further increase the gap.

Current efforts at relief of poverty are designed merely to pacify protesters. These efforts create the illusion that we are trying to define and measure poverty and to think about how it can be alleviated. At the center of these efforts is the false and misleading idea that "scarcity" is the root of the economic problem; see Zaman (2010a; 2012) for a rebuttal of this idea. The wrong diagnosis of scarcity leads to current efforts to increase wealth through growth as the cure for poverty. In fact, additional wealth generated in this process is captured by the rich and powerful leading to increasing inequality and poverty accompanied by increasing growth.

Islamic teachings assert that it is not scarcity, but misuse of existing wealth and material possessions which leads to poverty and inequality. Solutions require re-distribution of wealth from the rich to the poor and not accumulation of more wealth. Furthermore, since the wealthy are powerful, this re-distribution cannot be achieved by force. It can be achieved by awakening the feelings of sympathy and compassion which exist within the heart of everyone. Due to the misconception that greed would lead to accumulation of wealth, which would eventually eliminate poverty, the west has encouraged and legit- 
imized greed ${ }^{(18)}$. This has led to a situation where massive amounts of luxury and opulence co-exist with massive amounts of misery and poverty in the world we see around us. The greed of the rich prevents them from using their wealth to help the poor:

And among them are such as vow unto God, "If indeed He grant us [something] out of His bounty, we shall most certainly spend in charity, and shall most certainly be among the righteous"! But as soon as He has given them [aught] out of His bounty. they cling to it niggardly, and turn away in their obstinacy [from all that they have vowed]. (Qur'ān, 9:75-76)

Instead of seeking wealth so as to be able to give in charity, Islam teaches us to give in charity from whatever we have. This attitude of generosity and giving leads to a society where those who have, feel responsible for those who don't. This is what leads to solutions for poverty.

The idea that we can find solutions to poverty working within a framework of competition and greed is seriously mistaken. The Islamic economy is based on the principles of generosity and cooperation. Mutual dependence is the basis of society, where we all help one another so that none are seriously deprived. For a thousand years, Islamic society was able to take care of all its citizens, including minorities and females, and provide for their health, education, housing, food, and social welfare. This was accomplished by a multi-dimensional approach utilizing a broad array of mechanisms based on spiritual, social, institutional, and legal mechanisms. These addressed the needs of the poor for dignity, honor, equality, justice, and many other dimensions not addressed by current approaches.
With the Western conquest of the globe, these institutions and ways of thinking were extinguished and forgotten. Justification of the brutal and sordid process of colonization required the development of brutal ideologies which tolerate, and even celebrate, luxurious lifestyles of the rich and powerful in presence of the stark misery of billions. The Islamic alternative insight required was encapsulated by Mahbubul Haq as "people are both the means and the end of development" (Haq, 1995, p. 3). That is, if we focus on the spiritual and social development of human beings, as required by Islam, we will arrive at the solutions to the larger problems. Now, instead of looking to their rich heritage, Muslims are looking for solutions from capitalist market economies which have destroyed families, communities, and the environment necessary for nurturing the weak and the oppressed, and have seen massive increases in inequalities. As the Qur'ān states

Say: In this bounty of God and in His grace (that is, the Quran), then, let them rejoice: it is better than all that they may amass! (Qur'ān, 10:58)

Indeed, it is true that the rich and multi-dimensional set of solutions offered to the problems of poverty and inequality by the Qur'ān is far better than anything currently available in the massive literature on poverty. Generally speaking this literature takes the capitalist framework of greed and competition as given and tries to find solutions within this framework. Islam came as a stranger and revolutionized the world. The conceptual framework it offers remains revolutionary and offers solutions to deep and difficult problems currently facing humanity. It remains to be seen whether Muslims can shoulder the burden of responsibility placed upon them to serve as beacons of guidance for the world to follow.

(18) A classic expression of this mistake is Keynes' "we have exalted some of the most distasteful of human qualities [love of money] into the position of the highest virtues... For at least another hundred years we must pretend to ourselves and to everyone that fair is foul and foul is fair; for foul is useful and fair is not. Avarice and usury and precaution must be our gods for a little longer still. For only they can lead us out of the tunnel of economic necessity into daylight" (Keynes, 1933, pp. 369 -372). 


\section{References}

Abu Dawood, Sulaiman bin Ashath. (2009). Sunan Abi Dawood, Beirut: Dar al-Risalah al-Aalamiyyah.

Abu Yusuf, Yaqoob bin Ibrahim. (1979). Kitab alKharaj [The Book of Taxation]. Beirut: Dar alMa'rifah.

al-Bukhari, Muhammad bin Ismail. (1422H [2001]). Sahih al-Bukhari. Beirut: Dar Tawq al-Najah.

al-Bayhaqi, Ahmad bin al-Hussain. (2003). Shu'ab alImān [Branches of $\bar{m} \bar{a} n$ ]. Riyadh: Maktabah al-Rushd.

Cohen, A. J., \& Harcourt, G. C. (2003). Retrospectives: whatever happened to the Cambridge capital theory controversies? Journal of Economic Perspectives, 17(1), 199-214.

Easterlin, R. A., McVey, L. A., Switek, M., Sawangfa, O., \& Zweig, J. S. (2010). The happiness-income paradox revisited. Proceedings of the National Academy of Sciences of the United States of America (PNAS), 107(52), 22463-22468.

Epps, G. (2011, June 23). Constitutional Myth \#5: Corporations Have the Same Free-Speech Rights as Individuals. The Atlantic. Retrieved from: https://www.theatlantic.com/national/archive/2011/06/c onstitutional-myth-5-corporations-have-the-same-freespeech-rights-as-individuals/240874/

Galbraith, J. K. (1998). The affluent society. Boston, Massachusetts: Houghton Mifflin Harcourt, 1998.

Gauthier, D. (1986). Morals by Agreement. Oxford: Clarendon Press.

George, D. L. (2001). Preference Pollution: How markets create the desires we dislike. Michigan: University of Michigan Press.

al-Ghazali, Muhammad bin Muhammad. (2005). Ihya' Uloom al-Din. Beirut: Dar Ibn Hazm.

Glover, J. (2001). Humanity: A Moral History of the Twentieth Century. New Haven, Connecticut: Yale University Press.

Goodwin, N. R., Ackerman, F., \& Kiron, D. (Eds.). (1997). The Consumer Society. Washington, DC, and Covelo, CA: Island Press.

Goody, J. (2012). The Theft of History. Cambridge, UK: Cambridge University Press.

Halberstam, D. (2002). The best and the brightest. New York: Modern Library.

Haq, M. (1995). Reflections on Human Development: How the focus of development economics shifted from national income accounting to people-centred policies, told by one of the chief architects of the new paradigm. New York: Oxford University Press.
Himmelfarb, Gertrude. (1984). The Idea of Poverty: England in the early Industrial Age. New York: Alfred A. Knopf.

Hodgson, M. G. S. (2009). The Venture of Islam, Volume 1: The Classical Age of Islam. Chicago: University of Chicago Press.

Hobbes, T. (1949). De Cive OR The Citizen. S. P. Lamprecht (Ed.). New York: Appleton-Century-Crofts.

Hobbes, T. (1909). Leviathan. Oxford: Clarendon Press.

Huntington, S. P. (2011). The Clash of Civilizations and the Remaking of World. New York: Simon \& Schuster.

Ibn al-Atheer, Ali bin Abi al-Karam. (1997). Al-Kāmil fi al-Tārikh [The Comprehensive History]. Beirut: Dar al-Kitab al-'Arabi.

Ibn Majah, Muhammad bin Yazid. (2009). Sunan Ibn Majah. Beirut: Dar al-Risaalah al-'Alamiyyah.

Ibn Sa'ad, Muhammad bin Sa'ad. (1968). Al-Tabaqāt al-Kubrā. Bierut: Dar Saadir.

Ibn al-Sary, Hannad. (1985). Al-Zuhd. Kuwait: Dar AlKhulafa' lil-Kitab al-Islami.

Kahf, Monzer. (1992). Waqf and its Socio-political Aspects. Draft Discussion paper. Jeddah: Islamic Research and Training Institute. Retrieved from: monzer.kahf.com/papers/english/WAQF_and_its_Soci opolitical_Aspects.pdf

Keynes, J. M. (1933). Economic Possibilities for our Grandchildren (1930). In Essays in Persuasion (pp. 358-373). London: Macmillan and Co.

Korten, D. C. (2015). When Corporations Rule the World (3rd ed.). California: Berrett-Koehler Publishers.

Lyubomirsky, S. (2008). The how of happiness: A scientific approach to getting the life you want. New York: Penguin Group.

Manicas, P. T. (1987). A History and Philosophy of the Social Sciences. New York: Basil Blackwell.

Mankiw, N. G., \& Taylor, M. P. (2007). Macroeconomics European Edition (6th ed.). VA: Worth Publishers.

Marglin, S. (2008). The Dismal Science: How thinking like an economist undermines community. Cambridge, MA: Harvard University Press.

el-Marsafy, Ziad. (2009). The Enlightenment Qur'an: The Politics of Translation and the Construction of Islam. London: Oneworld Publications.

Marx, Karl. (1959). Economic \& Philosophic Manuscripts of 1844 (Martin Milligan, Trans.). Moscow: Progress Publishers. 
Menocal, M. R. (2002). The Ornament of the World: How Jews, Christians, and Muslims Created a Culture of Tolerance in Medieval Spain. Boston: Little, Brown and Company.

Nadvi, Syed Abul Hassan Ali. (1986). Tahzeeb aur Tamaddun par Islam kay Ihsanat aur Asarat. [The Gifts and Effects of Islam on World Culture and Civilization]. Karachi: Majlis-e-Nashriat-e-Islam.

al-Naisabouri, Muslim bin al-Hajjaj. (1991). Sahih Muslim. Beirut: Dar Ihya' al-Turath al-Arabi.

Naz, M. S. (1999). Islami Riyasat main Muhtasib ka Kirdar [The Role of the Muhtasib in an Islamic State]. Islamabad: Islamic Research Institute, International Islamic University Islamabad.

Oakeshott, М. (1975). On Human Conduct. Oxford: Clarendon Press.

Olson, M. (2009). The logic of collective action: Public Goods and the Theory of Groups. Cambridge, MA: Harvard University Press.

Parkinson, J. E. (1995). Corporate power and responsibility: Issues in the theory of company law. Oxford: Clarendon Press.

Polanyi, K. (1944). The Great Transformation: The Political and Economic Origins of Our Time. New York: Farrar \& Rinehart Inc.

Raju, C. K. (2009). Dissenting knowledges pamphlet series (no. 8). Is Science Western in Origin? New Delhi, India: Daanish Books.

Reuben, J. A. (1996). The making of the modern university: Intellectual transformation and the marginalization of morality. Chicago: University of Chicago Press.

Robbins, R. H. (1999). Global Problems and the Culture of Capitalism. Boston: Allyn \& Bacon.

Sait, S., \& Lim, H. (2006). Land, Law and Islam: Property and Human Rights in the Muslim World. London: Zed Books.

Schor, J. B. (1999). The overspent American: Why we want what we don't need. New York: HarperPerennial.

Sen, Amartya. (2000). Social Exclusion: Concept, Application, And Scrutiny (Social Development Papers No. 1, Office of Environment and Social Development, Asian Development Bank). Retrieved from: http://www.adb.org/sites/default/files/publication/2977 8/social-exclusion.pdf

Shafi, Mufti Muhammad. (1979). Distribution of Wealth in Islam (Muhammad Hasan Askari, \& Karrar Husain, Trans.). Karachi: Begum Aisha Bawany Wakf.
Shalaby, Ahmed. (1954). History of Muslim Education. Beirut: Dar al-Kashaf.

Skidelsky, R. (2001). Keynes and the Ethics of Capitalism. Paper presented at Boston College, Chestnut Hill, MA. Retrieved from: http://www.oocities.org/monedem/keyn.html

al-Shaibani, Ahmad bin Hanbal. (2001). Musnad alImam Ahmad bin Hanbal. Beirut: Mu'assasah AlRisalah.

Spellberg, D. A. (2013). Thomas Jefferson's Qur'an: Islam and the Founders. New York: Vintage Books.

Stavrianos, L. S. (1981). Global Rift: The Third World Comes of Age. New York: William Morrow \& Co.

al-Tabarani, Sulaiman bin Ahmad. (1994). Al-Mu'jam al-Kabeer. Cairo: Maktabah Ibn Taymiyyah.

al-Tabarani, Sulaiman bin Ahmad. (1995). Al-Mu'jam al-Awsat. Cairo: Dar al-Haramain.

Tawney, R. H. (1937). Religion and the Rise of Capitalism (revised edition). New York: Harcourt, Brace and World, Inc.

al-Tirmidhi, Muhammad bin Eisa. (1975). Sunan alTirmidhi. Cairo: Makatabah wa Matba'ah Mustafa alBabi al-Halabi.

Toynbee, A. J. (1948). Civilization on Trial. New York: Oxford University Press.

Veblen, T. (1899). The Theory of the Leisure Class: An Economic Study of Institutions. New York: The Macmillan Company.

Ware, B. (2011). The Top Five Regrets of the Dying: A Life Transformed by the Dearly Departing. California: Balboa Press.

Weber, M. (1930). The Protestant Ethic and the Spirit of Capitalism (T. Parsons, Trans.). London: George Allen \& Unwin Ltd.

Zain al-'Abideen, Ali bin al-Husain. (n.d.). Treatise on Rights (Risalat Al-Huquq). Retrieved from: https://www.al-islam.org/treatise-rights-risalat-alhuquq-imam-zain-ul-abideen/rights-others\#32-rightneighbour

Zaman, Asad. (2010a). Scarcity: East and West. Journal of Islamic Economics, Banking and Finance, 6(1), 87104.

Zaman, Asad. (2010b). The Rise and Fall of the Market Economy. Review of Islamic Economics, 14(2), 123155.

Zaman, Asad. (2011). European Transition to Secular Thought: Lessons for Muslims. Unpublished Draft Discussion Paper. Retrieved from: https://sites.google.com/site/zamanislamicecon/extra- 
credit/non-eurocentric-history/european-historylessons-for-muslims

Zaman, Asad. (2012). The Normative Foundations of Scarcity. Real-World Economics Review, 61, 22-39.

Zaman, Asad. [AZ Islamic Economics]. (2017, Jan 28) Spirituality \& Development: Part 1, Spirituality (Lecture at Center of Development Studies, University of Cambridge) [video file]. Retrieved from: https://www.youtube.com/watch?v=urs-EkFa5go
Zarinebaf, Fariba. (2007, November). Ottoman Guilds and the State in $18^{\text {th }}$ Century Istanbul. Paper presented at the conference "The Rise and Decline of Imperial Leadership", Northwestern University, Evanston, Il.

Zuboff, S. (2009, July 2). The Old Solutions Have Become the New Problems. Business Week, Viewpoint. Retrieved from: https://www.bloomberg.com/news/articles/2009-0702/the-old-solutions-have-become-the-new-problems

Asad Zaman received his BS Math from MIT (1974), MS Stat, and PhD Economics from Stanford (1976) and (1978) respectively. He has taught at highly ranked international universities like Columbia, Penn., Cal. Tech. Currently, he is Vice Chancellor, at the Pakistan Institute of Development Economics and Acting Chief Economist Government of Pakistan. Previously he has held several top academic positions in Pakistan. His econometrics textbook Statistical Foundations of Econometric Techniques (Academic Press, NY, 1996) is widely used as a reference in graduate courses. He is also the managing editor of International Econometric Review. He has many publications in top ranked journals like Annals of Statistics, Journal of Econometrics, Econometric Theory, Journal of Labor Economics, etc. He has published widely in Islamic Economics and is a leading authority in the field. He has more than 550 citations as per Google Scholar.

E-mail: asadzaman@alum.mit.edu 


\section{مقاربة إسلامية لمشكلتي عدم المساواة والفقر

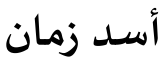 \\ نائب ملدير، معهد باكستان لاقتصياديات التنمية، إبلام آباد}

المستخلص. نقرر في هذه الورقة بأن النظريات وطرق التفكير حول الفقر تغيرت بشكل كبير بسبب "التحول الكبير" في أوروبا الذي أدى إلى خلق مجتمع السوق. وانتشرت هذه النظريات إلى بقية

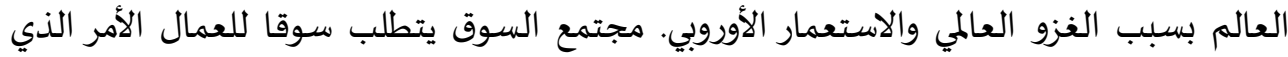
يسلب إنسانية الناس ويحولهم إلى سلع. هذا وغيره من التغيرات في المواقف ذات الصلة تجاه الغنى والفقر هي مصادر الصعوبات الناجمة عن الفقر وعدم المساواة. المقاربة الإسلامية لهاتين المسألتين تتطلب إعادة خلق المجتمع على أساسيّ الكرم والتعاون؛ القيم التي تتناقض مع الجشع والمنافسة، التي هي أساس مجتمعات السوق. نرسم في هذه الورقة نهجا ثلاثي الأبعاد لحل المشاكل الناشئة عن عدم المساواة والفقر، قائما على العناصر الروحية والاجتماعية والمؤسسية. وفي كل مجال، توفر مصادر الإسلام والتاريخ الإسلامي توجيهات وافرة لمقاربة مختلفة جذريا إزاء هذه المشاكل. 